Интернет-журнал «Транспортные сооружения» / Russian journal of transport engineering http://t-s.today/

2016, Том 3, №4 / 2016, Vol 3, No 4 http://t-s.today/issues/vol3-no4.html

URL статьи: http://t-s.today/PDF/05angTS416.pdf

DOI: 10.15862/05angTS416 (http://dx.doi.org/10.15862/05angTS416)

Ссылка для цитирования этой статьи:

Углова Е.В., Саенко С.С. Обзор инструментов прогнозирования продольной ровности дорожных покрытий // Интернет-журнал «Транспортные сооружения», Том 3, №4 (2016) http://t-s.today/PDF/05angTS416.pdf (доступ свободный). Загл. с экрана. Яз. рус., англ. DOI: 10.15862/05angTS416

For citation:

Uglova E.V., Saenko S.S. [Review of longitudinal pavement roughness prediction tools] Russian journal of transport engineering, 2016, Vol. 3, no. 4. Available at: http://t-s.today/PDF/05angTS416.pdf (In Russ.)

DOI: $10.15862 / 05$ angTS416

Uglova Evgenia Vladimirovna

Don state technical university, Russia, Rostov-on-Don

E-mail: uglova.ev@yandex.ru

Saenko Sergey Sergeevich

Don state technical university, Russia, Rostov-on-Don

E-mail: svkube@mail.ru

\title{
Review of longitudinal pavement roughness prediction tools
}

\begin{abstract}
Many road agencies use special tools for managing their assets. Article provides overview of most known pavement management systems. Most of all describing pavement management systems have special tools for prediction longitudinal roughness, rutting, friction, Pavement Conditional Index (PCI), Surface Distress Index (SDI), Structural Adequacy Index (SAI) and Ride Comfort Index (RCI) etc. Among the factors of performance deterioration the following external factors are the most frequently singled out: the number of freezing and thawing cycles, temperature, humidity, precipitation, ground water depth level, the number of traffic load repeats in daily average annual traffic intensity or equivalent single axle load (ESAL); internal factors: material type, structural strength and thickness, subgrade material, etc. There is an analysis of current longitudinal roughness prediction models, which are used on the project and network level, in the article. The article contains deterministic models of longitudinal roughness prediction suggested by Russian and foreign authors at different periods of times.
\end{abstract} roughness

Keywords: pavement management system; prediction models; pavement performance;

To ensure the most efficient asset management the highway agencies of developed countries use pavement management systems at network and project levels [1]. The key element of many of those systems is the capability to predict the occurrence of critical state of pavement performance and/or functional parameters which determine the type and sequence of repair, preventive and other measures taking into account actual financing. The table 1 based on the analyzed literature references [2-11] contains data on the prediction tools of the best known pavement management systems. 
Table 1

Prediction models used in various pavement management systems

\begin{tabular}{|c|c|}
\hline Expert system & Brief description of applied deterioration models \\
\hline PMAS & Markov models are used \\
\hline $\begin{array}{l}\text { AgilAssets®Pavement } \\
\text { Analist }\end{array}$ & $\begin{array}{l}\text { Prediction of pavement performance is based on the analysis of } \\
\text { performance deterioration curves }\end{array}$ \\
\hline PAVEMENTview & Doesn't have individual prediction models. Any models can be used \\
\hline PERS & Doesn't have individual prediction models \\
\hline ICON & Doesn't have individual prediction models. Any models can be used \\
\hline PMSPRO $^{\mathrm{TM}}$ & Doesn't have individual prediction models \\
\hline HPMA & Prediction models of PCI or another indices \\
\hline MicroPAVER & $\begin{array}{l}\text { Prediction of pavement performance is based on the analysis of PCI } \\
\text { deterioration curves }\end{array}$ \\
\hline TAMS & $\begin{array}{l}\text { Prediction of pavement performance is based on the analysis the } \\
\text { historical data }\end{array}$ \\
\hline Vejman.dk & Roughness models are used (IRI) \\
\hline dROAD/dTIMS & Roughness, rutting and damages models are used \\
\hline WDM & $\begin{array}{l}\text { Prediction of pavement performance is based on the analysis the } \\
\text { historical data }\end{array}$ \\
\hline Asset Manager NT & $\begin{array}{l}\text { Doesn't have own prediction models. Results of any another PMS use } \\
\text { for create scenario «what if» }\end{array}$ \\
\hline HDM-4 & $\begin{array}{l}\text { Roughness as result of structural deformation and defect development } \\
\text { are used. Rutting and Square of cracking can be used for prediction } \\
\text { separately }\end{array}$ \\
\hline Stantec PMS/RoadMatrix & $\begin{array}{l}\text { Deterioration models Surface Distress Index (SDI), Structural } \\
\text { Adequacy Index (SAI) and Ride Comfort Index (RCI) }\end{array}$ \\
\hline HIPS & Markov models are used \\
\hline RoSy® (PMS) & $\begin{array}{l}\text { Doesn't have individual prediction models. Prediction models of HDM- } \\
4 \text { are used }\end{array}$ \\
\hline RONET & Simplify prediction models of HDM-4 are used \\
\hline RoadMatrix $^{\mathrm{TM}}$ & Prediction models of Pavement Quality Index (PQI) al \\
\hline Norwegian PM System & Roughness and rutting models are used \\
\hline MEPDG & Prediction models of cracking and rutting are used \\
\hline FHWA HPMS & Prediction models of Pavement Serviceability Rating (PSR) are used \\
\hline CCPMS & Doesn't have prediction models \\
\hline LBPMS & Doesn't have prediction models \\
\hline RSMS99 & Doesn't have prediction models \\
\hline CTL PMS & Doesn't have prediction models \\
\hline dROADLOG & Doesn't have prediction models \\
\hline Dynatest PMS & Doesn't have prediction models \\
\hline PMSpro 2000 & Doesn't have individual prediction models. Any models can be used \\
\hline Visual/PMS ${ }^{\mathrm{TM}}$ & $\begin{array}{l}\text { Prediction of pavement performance is based on the analysis the } \\
\text { historical data }\end{array}$ \\
\hline DSS & Prediction models of Pavement Condition Index (PCI) are used \\
\hline MPMS & Prediction model of Pavement Structural Condition rating (PSC) is used \\
\hline Swedish PMS & Prediction models of HIPS are used \\
\hline ELMOD & Roughness, rutting, friction and wearing models are used \\
\hline
\end{tabular}


In the majority of the above management systems pavement management is carried out relying on performance indices which are the first and foremost to ensure comfortable driving.

Among the factors of performance deterioration the following external factors are the most frequently singled out: the number of freezing and thawing cycles, temperature, humidity, precipitation, ground water depth level, the number of traffic load repeats in daily average annual traffic intensity or equivalent single axle load (ESAL); internal factors: material type, structural strength and thickness, subgrade material, etc.

Many pavement management systems make use mainly of the deterioration-time relation. The typical deterioration curve is shown in fig. 1a. However, the nature of pavement deterioration is not always like this: inverted deterioration curves (fig. 1b) were obtained by Haas [12] during monitoring of the pavements designed for heavier traffic load than the observed one. In this case the crucial influence during the change of performance was exerted primarily by climate and weather.

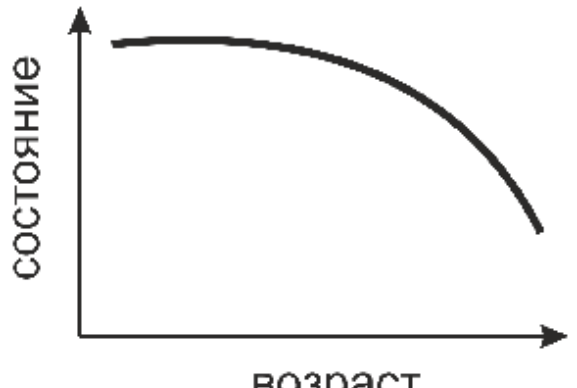

возраст

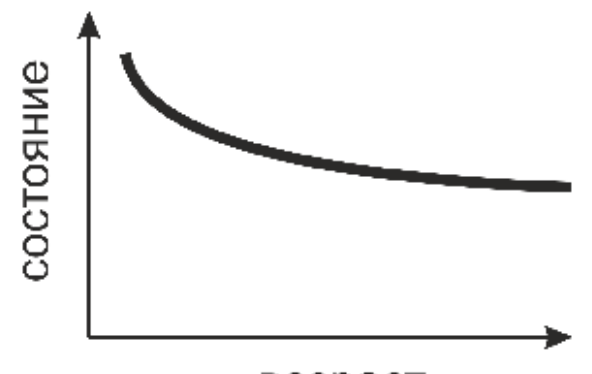

возраст

Figure 1. Pavement deterioration curves: $a$ - when the traffic load corresponds to the design load, $b$ - when the traffic load is lower than the design load

Raymond [13] points to high impact of local factors on performance deterioration. Some international models, including the World Bank's Highway Development and Management Model HDM-4 [14], allow the user to calibrate models according to local specific features.

In general, deterioration models may be divided into deterministic and probabilistic ones.

The deterministic model returns one state value for the predefined input data set [15]. Deterministic models are usually shown as functions. The simplest ones are based on linear regression, however exponential functions and other more complicated ones may return more exact results.

Further, deterministic models are divided into mechanistic (theory-based), empirical (experiment-based), mechanistic-empirical (theory and experiment combined) or those based on expert evidence.

Mechanistic models are based on physical laws. For example, pavement deterioration may need application of relations between stresses, strains, and loads. Typically mechanistic models as is are not applied in pavement management. Moreover, it is believed to be impossible: in [16] it is mentioned that there are no solely mechanistic models for deterioration prediction, in [17] it is stated that mechanistic models are impractical for prediction, although in [18] it is assumed that there are no absolutely mechanistic models, however there are no reasons preventing from their designing. Nevertheless, mechanistic models are not used in prediction of pavement condition due to a great number of aspects.

Empiric models are developed to predict conditions depending on such variables as age, type of material, loading conditions, etc., typically via regression. This type of models is often used when deterioration cannot be explained mechanistically. Schram [19] found out that $91 \%$ of Canadian and American agencies used empirical models of performance deterioration. The majority of the countries 
of Northern Europe apply empirical linear extrapolation of the current condition of pavement in their management systems too [20].

Many deterioration models (prediction models) fall into the mechanical-empirical category. They include calculation of mechanical reactions (for example, stresses, strains, etc.) and other measured variables for prediction of conditions. This type of models is often applied for performance deterioration modeling [13, 19, 21, 22]. The models yield good results and it is believed that they model deterioration more precisely than empiric models.

The following approaches are used to achieve deterministic models [23]:

- $\quad$ straight (or simple??) linear extrapolation;

- $\quad$ regression analysis (linear, multiple, special);

- $\quad$ polynomial interpolation (least square method);

- $\quad$ exponential analysis.

Linear extrapolation is used for performance prediction when a limited survey data amount is available. It was ascertained [24] that the deterioration curve had not linear, but curvilinear shape; that is why this approach is used for specific road sections only.

Multiple linear regression is one of the simplest forms of the deterministic model and is used when more than one factor influences a dependent variable [15]. The following equation conforms to the model:

$$
\hat{y}=b_{0}+x_{1} b_{1} \ldots+x_{k} b_{k}
$$

where $b_{0}, b_{1} \ldots b_{k}$ are regression coefficients, $\hat{y}$ is a predicted value of the dependent variable, $x_{1} \ldots x_{k}$ are values of independent variables. Concerning pavement deterioration $\hat{y}$ is a parameter of performance, $x_{1} \ldots x_{k}$ are factors influencing the condition (age, materials, location, traffic intensity, etc.). To find coefficients $b_{0}, b_{1} \ldots b_{k}$ the least square method is typically used.

Exponential (S-curve) is usable in predicting of variable changes (for example, that pertinent to driving comfort) as function of the other variable (for example, age of road structure).

In probabilistic models the output parameter is probability that the asset (for example, road structure) is in a specific condition for the suggested input parameter set. There are many different types of models in this group.

One of the most popular probabilistic models used in asset deterioration modeling is Markov chain [15]. Markov models give probability $p_{i j}$ that the element in $i$ condition at $t$ time step will be in $j$ condition at $t+1$ time step. These transition probabilities are arranged in the transition matrix:

$$
P^{t, t+1}=P\left(X_{t+1}=j \mid X_{t}=i\right)=\left[\begin{array}{ccc}
p_{11} & \ldots & p_{1 j} \\
\ldots & \ddots & \ldots \\
p_{i 1} & \ldots & p_{i j}
\end{array}\right]
$$

where $p_{i j} \geq 0 ; i, j \geq 1 ; \sum_{k=1}^{j} p_{i, k}=1$.

Distribution of the asset (road structure) chain conditions at $(t+n)$ time can be found through the product of the current distribution and transition matrixes:

$$
Q(t+n)=Q(t) P^{t, t+1} P^{t+1, t+2} \ldots P^{t+n-1, t+n}
$$

During deterioration modeling $p_{i j}$ is usually defined as probability of deterioration of $i$ condition to $j$ condition. 
While in the time homogeneous Markov model the prediction condition depends on the current condition only, in semi-Markov or nonhomogeneous models the independently distributed random values are used for time modeling between states. Thus, the model depends on time. From the point of view of the tangible asset deterioration it means that probability of deterioration to the next condition increases with the asset age. Semi-Markov models require more data for definition of additional parameters and are more complicated in implementation than the time-homogeneous Markov model [25].

The other commonly used probabilistic model is logistic regression. Unlike multiple linear regression where output characteristic is asset condition, logistic regression defines probability of the asset being in a specific condition with the predefined set of independent variables [15]:

$$
E(Y=y \mid X)=P=\frac{1}{1+e^{-\left(b_{0}+\sum_{i=1}^{k} b_{i} x_{i}\right)}}
$$

The literature shows various models of pavement longitudinal roughness deterioration. They may be classified into four categories: models related to structure effect; models based on temporal effect; models considering correlation between temporal and structure factors; and models where structure, surface and temporal effects define longitudinal roughness.

The table 2 contains deterministic models of longitudinal roughness prediction suggested by Russian and foreign authors at different periods of times.

Deterministic prediction models of longitudinal roughness

Table 2

\begin{tabular}{|c|c|}
\hline Reference & Model \\
\hline [26] & $\begin{array}{l}\qquad R_{t}=R_{0}+s(S) N_{t} \\
\text { where: } s(S) \text { - function of modified structural number, } \\
R_{0}, R_{t} \text { - roughness at time } 0 \text { and t, respectively, } \\
N_{t} \text { - cumulative number of equivalent } 18 \text {-kip }(80 \mathrm{kN}) \text { standard axle loads to time. }\end{array}$ \\
\hline [27] & $\begin{array}{l}\qquad S_{t}=S_{0}\left[1+c \cdot E_{\min }^{d}\left(n N_{1} \frac{q^{t}-1}{q-1}\right)^{a \cdot E_{\min }^{b}}\right] \\
\text { where: } S_{t} \text { и } S_{0} \text { - roughness at times } \mathrm{t} \text { and } \mathrm{t}=0 \text { respectively by Bump Integrator, } \\
\mathrm{cm} / \mathrm{km}, \\
a, b, c, d \text { - coefficients determined for each data set, } \\
n \text { - duration of design period, day/year, } \\
N_{1} \text { - number of traffic load at first year, } \\
q \text { - traffic volume increment in time } t, \\
E_{\text {min }} \text { - minimum requirement E-modulus, MPa. }\end{array}$ \\
\hline [28] & $\begin{array}{l}\qquad \Delta R_{t}=a R_{t} \Delta t-b \\
\text { where: } \Delta t \text { - increment in time, } \\
a, b \text { - constant parameters which are environmental parameters of rainfall, } \\
\text { elevation, freeze-thaw cycles, temperature, etc., } \\
R_{t}-\text { roughness, in } / \mathrm{m} \text {. }\end{array}$ \\
\hline [29] & $\begin{array}{l}\qquad R_{t}=\mathrm{C}_{0}+\mathrm{C}_{1} t \\
\text { where: } R_{t} \text { - roughness of homogenous section, in } / \mathrm{m} \text {, } \\
t \text { - year since the treatment, } \\
\mathrm{C}_{0}, \mathrm{C}_{1} \text { - regression coefficients. }\end{array}$ \\
\hline [30] & $\begin{array}{l}\qquad R_{t}=R_{0}+a t^{b} \\
\text { where: } t \text { - pavement age, in years, } \\
a, b \text { - coefficients determined for each data set. }\end{array}$ \\
\hline
\end{tabular}




\begin{tabular}{|c|c|}
\hline Reference & Model \\
\hline [31] & $\begin{array}{l}\qquad I R I_{d}=I R I_{i}+\left(I R I_{1}+I R I_{i}\right)\left(\frac{A_{d}}{A_{1}}\right)^{1.5} \\
\text { where: } I R I_{d} \text { - predicted roughness at a desired future date, } \mathrm{mm} / \mathrm{m} \text {, } \\
I R I_{i} \text { - roughness just after the latest rehabilitation, } \mathrm{mm} / \mathrm{m}, \\
I R I_{1} \text { - latest recorded roughness, } \mathrm{mm} / \mathrm{m} \text {, } \\
A_{d} \text { - age of the pavement surface at the desired future date, years, } \\
A_{1} \text { - age of the pavement surface when the latest roughness recording was made, } \\
\text { years. }\end{array}$ \\
\hline$[32,33]$ & $\begin{array}{l}\qquad P S C=C+\left(m A^{P}\right) \\
\text { where: } A \text { - age of pavement since overlay or construction, years, } \\
C \text { - model coefficient }(\sim 100), \\
m \text { - slope coefficient, } \\
P \text { - constant. }\end{array}$ \\
\hline [34] & $\begin{array}{l}\qquad I R I=I R I_{0}+e^{\left(a-b \cdot c^{x}\right)} \\
\text { where: } I R I-\text { predicted roughness at a desired future date, } \mathrm{m} / \mathrm{km} \text {, } \\
I R I_{0}-\text { roughness at time } 0, \mathrm{~m} / \mathrm{km}, \\
x=\ln (t) \\
t-\text { age of pavement, years, } \\
a, b, c \text { - model coefficients. }\end{array}$ \\
\hline [35] & $\begin{array}{l}\qquad I R I=42+1,8 \cdot A G E+0,0004 \cdot A A D T \\
\text { where: } A G E \text { - age of pavement since overlay or construction, years, } \\
A A D T \text { - average annual daily traffic, veh/day. }\end{array}$ \\
\hline [36] & $\begin{array}{l}\qquad S_{t}=\alpha \cdot Q_{t}+\beta \\
\text { where: } \alpha \text { - empirical coefficient for particular local conditions, } \\
\beta \text { - roughness at time } 0 \text { just after the latest rehabilitation by Bump Integrator, } \mathrm{cm} / \mathrm{km} \text {, } \\
Q_{t} \text { - total load intensity for t period, million gross tonn. }\end{array}$ \\
\hline $\begin{array}{l}\text { ДМД } \\
02191.5 .011- \\
2011\end{array}$ & $\begin{array}{l}\qquad I R I_{T}=I R I_{0}+K \frac{\sum_{1}^{T} N}{10^{6}} \cdot \frac{I R I_{0}}{I R I_{H}} \\
\text { where: } I R I_{T} \text { - predicted roughness at time } T, \mathrm{~mm} / \mathrm{m}, \\
I R I_{0} \text { - roughness at time } 0, \mathrm{~mm} / \mathrm{m} \text {, } \\
I R I_{H} \text { - roughness just after the latest rehabilitation, } \mathrm{mm} / \mathrm{m}, \\
\sum_{1}^{T} N \text { - total number of traffic load in estimate period } \mathrm{T}, \text { number } / \text { lane, } \\
K \text { - model coefficient. }\end{array}$ \\
\hline [23] & $\begin{array}{l}\qquad R I_{t}=\left[R I_{0}+725(1+S N C)^{-4.99} N E_{4 t}\right] e^{0.0153 t} \\
\text { where: } R I_{t}, R I_{0} \text { - roughness at times } \mathrm{t} \text { and } \mathrm{t}=0 \text { respectively, } \mathrm{m} / \mathrm{km} \text {, } \\
N E_{4 t} \text { - cumulative equivalent standard axle loadings until time } \mathrm{t} \text {, million ESA/lane, } \\
t \text { - age of pavement since overlay or construction, years, } \\
S N C \text { - modified structural number. }\end{array}$ \\
\hline
\end{tabular}




\begin{tabular}{|c|c|}
\hline Reference & Model \\
\hline [37] & $\begin{array}{l}\quad \Delta I R I_{i}=k_{r}[196.74 \cdot S T R U C+0.016 \cdot \Delta c r x+0.25 \cdot \Delta r u t+0.972 \cdot E N V I R] \\
\text { where: } k_{r} \text { - calibration coefficient for roughness, } \\
\Delta I R I_{i} \text { - cumulative lane roughness at the year «i» after the initial roughness IRI } I_{0} \text {, } \\
\mathrm{m} / \mathrm{k}), \\
\Delta r u t \text { - cumulative lane rut depth at the year «i» after initial densification, mm, } \\
\Delta c r x-\text { cumulative percentage area of cracking after cracking has commenced, \% } \\
S T R U C \text { - cumulative structural condition of the pavement «i» years after } \\
\text { construction/rehabilitation under traffic loading, } \\
E N V I R \text { - cumulative environmental damage on the pavement «i»years after } \\
\text { construction/rehabilitation. }\end{array}$ \\
\hline$[38,39]$ & $\begin{array}{l}\quad d I R I=k_{g p}\left(a_{0} e^{k_{g m} m A G E}\left(1+S N C a_{1}\right)^{-5} N E_{4 t}+a_{2} A G E\right)+k_{g m} m R I_{a} \\
\text { where: } k_{g p} \text { - coefficient of degradation rate, } \\
a_{0}, a_{1}, a_{2} \text { - coefficients HDM-4, } \\
m \text { - climate factor, } \\
A G E \text { - pavement age, years, } \\
S N C \text { - modify structural number, } \\
N E_{4 t} \text { - total ESAL up to time t, million ESA/lane, } \\
R I_{a} \text { - current value of roughness IRI, } \mathrm{m} / \mathrm{km} \text {. }\end{array}$ \\
\hline [11] & $\begin{array}{l}\qquad I R I_{t}=I R I_{0}+a\left(\frac{N}{10^{6}}\right)^{b} \\
\text { where: } I R I_{0}, I R I_{t} \text { - roughness at times } \mathrm{t} \text { and } \mathrm{t}=0 \text { respectively, } \mathrm{m} / \mathrm{km} \text {, } \\
N \text { - total number of vehicle during analyzing period, vehicle, } \\
a, b \text { - model coefficients. }\end{array}$ \\
\hline
\end{tabular}

\section{REFERENCES}

1. Uglova E.V., Saenko S.S. Obzor instrumentov upravleniya sostoyaniem dorozhnykh konstruktsiy // Internet-zhurnal «Transportnye sooruzheniya», Tom 3, №1 (2016) [Uglova E., Saenko S. Review of pavement management tools // Russian journal of transport engineering, Book 3, №1 (2016) http://t-s.today/PDF/02TS116.pdf].

2. Analytical Tools for Asset Management. NCHRP report 545. Washington, 2005. 71 p.

3. Hausman, J., Speir, R., Larrazabal, E. Pavement Management System Implementation for Howland Hook Container Terminal. 6th International Conference on Managing Pavements, 2004.

4. IDS - Infrastructure Decision Support. URL: http://www.ids.org.nz/.

5. Lang J.M. Pavement Management Systems in Sweden. 5th International Conference on Managing Pavements, 2001.

6. MicroPAVER Implementation and Pavement Condition Index (PCI) Survey Project. State of the Streets Report including MicroPAVER Technical Documentation. Chicago. $34 \mathrm{p}$.

7. Morosiuk G., Riley M.J., HDM-4. Odoki J.B. Modelling Road Deterioration and Work Effects. Version 2. Volume 6, 2004. 297 p.

8. Pavement Performace Models (NordFoU - PPM). Summary report. Denmark, Iceland, Norway, Sweden, 2011. 39 p. 
9. Scullion T. et al. TxDOT's Pavement Management Information System: Current status and future directions. Research report 1420-S, Texas Transportation Institute, 1997. 127 p.

10. Shahin M.Y. Pavement Management - MicroPAVER Update. 5th International Conference on Managing Pavements, 2001.

11. Training Evaluation of Layer Moduli and Overlay Design. Dynatest ELMOD 6 brochure by Alessandro Marradi. Saint Brieuc. 18-20 February 2015.

12. Haas, R. (ed) 1997, Pavement design and management guide, Transportation Association of Canada, Ottawa.

13. Raymond, C., Tighe, S., Haas, R. \& Rothenburg, L. 2003. Development of Canadian asphalt pavement deterioration models to benchmark performance. Canadian Journal of Civil Engineering, 30(4): 637-643.

14. Kerali, H.R., Robinson, R. \& Paterson, W.D.O. 1998. Role of the New HDM-4 in Highway Management. 4th International Conference on Managing Pavements, Transport Research Laboratory, Durban, South Africa, 801.

15. Abra Ens. Development of a Flexible Framework for Deterioration Modelling in Infrastructure Asset Management. Department of Civil Engineering University of Toronto 2012. $86 \mathrm{p}$.

16. Prozzi J.A., Madanat S.M. A Non-linear Model for Predicting Pavement Serviceability. Applications of Advanced Technologies in Transportation (2002): pp. 481-488.

17. Rauhut J.B., Gendell D.S. Proposed development of pavement performance prediction models from SHRP/LTPP Data. 2nd North American Pavement Management Conference. 17 p.

18. Lytton R.L. Concepts of pavement performance prediction and modeling. 2nd North American Pavement Management Conference.1987.

19. Schram, S.A. 2008, Mechanistic-empirical modeling and reliability in network-level pavement management, North Dakota State University.

20. Saba, R.G. 2006, Pavement Performance Prediction Models Project, NordFoU, Norway.

21. Ullidtz, P. 1999. Deterioration Models for Managing Flexible Pavements. Transportation Research Record: Journal of the Transportation Research Board, 1655 (-1): 31-34.

22. Tighe, S., He, Z. \& Haas, R. 2001. Environmental Deterioration Model for Flexible Pavement Design: An Ontario Example. Transportation Research Record: Journal of the Transportation Research Board, 1755 (-1): 81-89.

23. Using Pavement Performance Data to Develop Mechanistic-Empirical Concepts for Deteriorated and Rehabilitated Pavements. FHWA Report FH WA-RD-93-162, Virginia, 1994.

24. Shahin M.Y., "Pavement Management for Airports, Roads and Parking Lots". VNR, New York, NY, 2011.

25. Black, M., Brint, A.T. \& Brailsford, J.R. 2005. A Semi-Markov Approach for Modelling Asset Deterioration. Journal of the Operational Research Society, 56 (11): 1241-1249.

26. Evaluation of Surface Friction Guidelines for Washington State Highways. Final report. WA-RD 312.1. Washington, 1993. 99 p.

27. Planirovanie dorozhno-remontnykh rabot na osnove prognozirovaniya transportnoekspluatatsionnogo sostoyaniya avtomobil'nykh dorog: Metodich. Ukazaniya / Sh.Kh. 
Bekbulatov, O.A. Krasikov i dr.; Minstroy Resp. Kazakhstan. - Alma-Ata, 1993. - 36 s. [Bekbulatov Sh.H., Krasikov O.A. Planning of pavement repair works in accordance with prediction performance].

28. Way G.B. and Eisenberg J., "Pavement Management System for Arizona Phase 11: Verification of Performance Prediction Models and Development of Data Base", Arizona Department of Transportation, 1988.

29. Zaniewski J.P., Perera R. W. and Mamlouk M.S., "Feedback of Pavement Management Performance Data for Pavement Design", Transportation Research Record 1272, Washington, DC, 1990.

30. Potter D.W., "The Development of Road Roughness with Time-An Investigation", Internal Report AAIR 346-1, Australian Road Research Board, Melbourne, 1972.

31. Haugadegird T., Johansen J.M., Bertelsen D., Gabestad K. Norwegian Public Roads Administration: A Complete Pavement Management System in Operation. 3rd International Conference on Managing Pavements, 1994. Pp. 25-33.

32. Hagenlock E., Zimmer D., Hillesland S. Overview of the Mobility Pavement Management System (MPMS), Washington, 2012. 10 p.

33. Kay, R.K., Mahoney, J.P., \& Jackson, N.C. (1993). The WSDOT Pavement Management System - A 1993 Update. Seattle: Washington State Transportation Center.

34. Salem O., El-Assaly A., AbouRizk S. Performance Prediction Models of Pavement Highway Network in Alberta. TRB 2003 Annual Meeting.

35. Gulen S., Zhu K., Weaver J., Shan J., Flora W.F. Development of improved pavement performance prediction models for the Indiana pavement management system. Final report. FHWA/IN/JTRP-2001/17.

36. Slobodchikov Yu.V. Obosnovanie otsenochnykh pokazateley vybora remontnoy strategii avtomobil'nykh dorog $\mathrm{s}$ dorozhnymi odezhdami nezhestkogo tipa $\mathrm{V}$ izmenyayushchikhsya usloviyakh ekspluatatsii. - M.: Informavtodor, 1994. - 189 s. [Slobodchikov Y.V. Pavement repair strategy substantiation in varied condition of road operation].

37. Hui Chen and Dr. Tim Martin dTIMS Asset Management Tool User Documentation. Contract report for WALGA, 2012, $79 \mathrm{p}$.

38. Gonzalez, R. Evaluation of pavement surface friction seasonal variations - Thesis of faculty of the Virginia Polytechnic Institute and State University, degree of Master of Science in Civil and Environmental Engineering, 2009.

39. Guide for Mechanistic-Empirical Design of new and rehabilitated pavement structures. NCHRP report, 2004. 


\title{
УДК 625.76
}

Углова Евгения Владимировна ФГБОУ ВПО «Донской государственный технический университет», Россия, Ростов-на-Дону 1 Заведующий кафедрой «Автомобильные дороги» Доктор технических наук, профессор E-mail: uglova.ev@yandex.ru

Саенко Сергей Сергеевич ФГБОУ ВПО «Донской государственный технический университет», Россия, Ростов-на-Дону Доцент кафедры «Автомобильные дороги» Кандидат технических наук E-mail: svkube@ mail.ru

\section{Обзор инструментов прогнозирования продольной ровности дорожных покрытий}

\begin{abstract}
Аннотация. Многие дорожные агентства для эффективного управления активами пользуются специализированными инструментами. В статье представлен обзор наиболее известных систем управления состоянием дорожных конструкций. Многие из рассмотренных систем управления дорожных конструкций используют инструменты прогнозирования таких показателей как продольная ровность, колейность, коэффициент сцепления, Pavement Conditional Index (PCI), Surface Distress Index (SDI), Structural Adequacy Index (SAI) and Ride Comfort Index (RCI) и др. Агентства используют как простые линейные модели деградации параметров, так и вероятностные подходы (например, модели Маркова). Среди факторов ухудшения эксплуатационного состояния чаще всего выделяют следующие внешние факторы: число циклов замораживания / оттаивания, температура, влажность, осадки, глубина залегания грунтовых вод, число повторений транспортной нагрузки в среднесуточной годовой интенсивности движения или эквивалентной единичной осевой нагрузке (ESAL); внутренние факторы: тип материала, прочность и толщину конструкции, материал земляного полотна и др. Проведен анализ моделей прогнозирования продольной ровности используемых на проектном и сетевом уровнях. Представлены детерминистические модели прогнозирования продольной ровности, предложенные отечественными и зарубежными авторами в разные годы.
\end{abstract}

Ключевые слова: система управления состоянием дорожных конструкций; модели прогнозирования; эксплуатационное состояние; продольная ровность

\section{ЛИТЕРАТУРА}

1. Углова Е.В., Саенко С.С. Обзор инструментов управления состоянием дорожных конструкций // Интернет-журнал «Транспортные сооружения», Том 3, №1 (2016) [Uglova E., Saenko S. Review of pavement management tools // Russian journal of transport engineering, Book 3, №1 (2016) http://t-s.today/PDF/02TS116.pdf].

2. Analytical Tools for Asset Management. NCHRP report 545. Washington, 2005. 71 p.

3. Hausman, J., Speir, R., Larrazabal, E. Pavement Management System Implementation for Howland Hook Container Terminal. 6th International Conference on Managing Pavements, 2004.

\footnotetext{
1344000, г. Ростов-на-Дону, ул. Социалистическая 162
} 
4. IDS - Infrastructure Decision Support. URL: http://www.ids.org.nz/.

5. Lang J.M. Pavement Management Systems in Sweden. 5th International Conference on Managing Pavements, 2001.

6. MicroPAVER Implementation and Pavement Condition Index (PCI) Survey Project. State of the Streets Report including MicroPAVER Technical Documentation. Chicago. $34 \mathrm{p}$.

7. Morosiuk G., Riley M.J., HDM-4. Odoki J.B. Modelling Road Deterioration and Work Effects. Version 2. Volume 6, 2004. 297 p.

8. Pavement Performace Models (NordFoU - PPM). Summary report. Denmark, Iceland, Norway, Sweden, 2011. 39 p.

9. Scullion T. et al. TxDOT's Pavement Management Information System: Current status and future directions. Research report 1420-S, Texas Transportation Institute, 1997. $127 \mathrm{p}$.

10. Shahin M.Y. Pavement Management - MicroPAVER Update. 5th International Conference on Managing Pavements, 2001.

11. Training Evaluation of Layer Moduli and Overlay Design. Dynatest ELMOD 6 brochure by Alessandro Marradi. Saint Brieuc. 18-20 February 2015.

12. Haas, R. (ed) 1997, Pavement design and management guide, Transportation Association of Canada, Ottawa.

13. Raymond, C., Tighe, S., Haas, R. \& Rothenburg, L. 2003. Development of Canadian asphalt pavement deterioration models to benchmark performance. Canadian Journal of Civil Engineering, 30(4): 637-643.

14. Kerali, H.R., Robinson, R. \& Paterson, W.D.O. 1998. Role of the New HDM-4 in Highway Management. 4th International Conference on Managing Pavements, Transport Research Laboratory, Durban, South Africa, 801.

15. Abra Ens. Development of a Flexible Framework for Deterioration Modelling in Infrastructure Asset Management. Department of Civil Engineering University of Toronto 2012. $86 \mathrm{p}$.

16. Prozzi J.A., Madanat S.M. A Non-linear Model for Predicting Pavement Serviceability. Applications of Advanced Technologies in Transportation (2002): pp. 481-488.

17. Rauhut J.B., Gendell D.S. Proposed development of pavement performance prediction models from SHRP/LTPP Data. 2nd North American Pavement Management Conference. $17 \mathrm{p}$.

18. Lytton R.L. Concepts of pavement performance prediction and modeling. 2nd North American Pavement Management Conference.1987.

19. Schram, S.A. 2008, Mechanistic-empirical modeling and reliability in network-level pavement management, North Dakota State University.

20. Saba, R.G. 2006, Pavement Performance Prediction Models Project, NordFoU, Norway.

21. Ullidtz, P. 1999. Deterioration Models for Managing Flexible Pavements. Transportation Research Record: Journal of the Transportation Research Board, 1655 $(-1): 31-34$. 
22. Tighe, S., He, Z. \& Haas, R. 2001. Environmental Deterioration Model for Flexible Pavement Design: An Ontario Example. Transportation Research Record: Journal of the Transportation Research Board, 1755 (-1): 81-89.

23. Using Pavement Performance Data to Develop Mechanistic-Empirical Concepts for Deteriorated and Rehabilitated Pavements. FHWA Report FH WA-RD-93-162, Virginia, 1994.

24. Shahin M.Y., "Pavement Management for Airports, Roads and Parking Lots". VNR, New York, NY, 2011.

25. Black, M., Brint, A.T. \& Brailsford, J.R. 2005. A Semi-Markov Approach for Modelling Asset Deterioration. Journal of the Operational Research Society, 56 (11): 1241-1249.

26. Evaluation of Surface Friction Guidelines for Washington State Highways. Final report. WA-RD 312.1. Washington, 1993. 99 p.

27. Планирование дорожно-ремонтных работ на основе прогнозирования транспортно-эксплуатационного состояния автомобильных дорог: Методич. Указания / Ш.Х. Бекбулатов, О.А. Красиков и др.; Минстрой Респ. Казахстан. Алма-Ата, 1993. - 36 с. [Bekbulatov Sh.H., Krasikov O.A. Planning of pavement repair works in accordance with prediction performance].

28. Way G.B. and Eisenberg J., "Pavement Management System for Arizona Phase 11: Verification of Performance Prediction Models and Development of Data Base", Arizona Department of Transportation, 1988.

29. Zaniewski J.P., Perera R. W. and Mamlouk M.S., "Feedback of Pavement Management Performance Data for Pavement Design", Transportation Research Record 1272, Washington, DC, 1990.

30. Potter D.W., "The Development of Road Roughness with Time-An Investigation", Internal Report AAIR 346-1, Australian Road Research Board, Melbourne, 1972.

31. Haugadegird T., Johansen J.M., Bertelsen D., Gabestad K. Norwegian Public Roads Administration: A Complete Pavement Management System in Operation. 3rd International Conference on Managing Pavements, 1994. Pp. 25-33.

32. Hagenlock E., Zimmer D., Hillesland S. Overview of the Mobility Pavement Management System (MPMS), Washington, 2012. 10 p.

33. Kay, R.K., Mahoney, J.P., \& Jackson, N.C. (1993). The WSDOT Pavement Management System - A 1993 Update. Seattle: Washington State Transportation Center.

34. Salem O., El-Assaly A., AbouRizk S. Performance Prediction Models of Pavement Highway Network in Alberta. TRB 2003 Annual Meeting.

35. Gulen S., Zhu K., Weaver J., Shan J., Flora W.F. Development of improved pavement performance prediction models for the Indiana pavement management system. Final report. FHWA/IN/JTRP-2001/17.

36. Слободчиков Ю.В. Обоснование оценочных показателей выбора ремонтной стратегии автомобильных дорог с дорожными одеждами нежесткого типа в изменяющихся условиях эксплуатации. - М.: Информавтодор, 1994. - 189 с. [Slobodchikov Y.V. Pavement repair strategy substantiation in varied condition of road operation]. 
37. Hui Chen and Dr. Tim Martin dTIMS Asset Management Tool User Documentation. Contract report for WALGA, 2012, 79 p.

38. Gonzalez, R. Evaluation of pavement surface friction seasonal variations - Thesis of faculty of the Virginia Polytechnic Institute and State University, degree of Master of Science in Civil and Environmental Engineering, 2009.

39. Guide for Mechanistic-Empirical Design of new and rehabilitated pavement structures. NCHRP report, 2004. 